Edubiotik: Jurnal Pendidikan, Biologi dan Terapan
ISSN 2528-679X (print), ISSN 2597-9833 (online)
Vol. 6, No. 01, February 2021, pp. 58 -65
Available online at:
http://ejurnal.budiutomomalang.ac.id/index.php/edubiotik

Research Article

open 2 Access

\title{
Development instrument science process skills biology for Junior High School
}

\author{
Rifda Tanfiziyah*, Budhi Akbar, Devi Anugrah
}

Biology Education, Muhammadiyah University Prof. Dr. HAMKA, Jakarta, Indonesia

Email: rifdatanfiziyah55@gmail.com, budhiakbar@gmail.com, devi.anugrah@uhamka.ac.id

\begin{tabular}{ll}
\hline Article Information & \multicolumn{1}{c}{ ABSTRACT } \\
\hline Submitted: 2020-08-15 & Science process skills (SPS) are basic skills in science and tools of a scientist to \\
Accepted: 2021-06-10 & investigate science phenomena. One of the ways to improve science process \\
Published: 2021-06-10 & skills is by giving students practice questions. This study aims to develop a valid \\
& and reliable science process skills instrument. The research is developmental \\
& research using a procedural model adapted from Djaali and Muljono. These steps \\
include the theory synthesis stage, the design stage (variable construction, \\
development of question indicators, preparation of grids, making instruments, \\
scoring), and the evaluation stage (validity test, reliability test, and item analysis). \\
The research instruments used were expert validation sheets, practitioner \\
assessment questionnaires, and product trial questions for 100 students. The \\
results of judgment expert and practitioner judgment were processed \\
descriptively. The empirical validity results, which are quantitative data, are \\
processed using the software Microsoft Excel. The results showed that the \\
developed questions were valid based on logical validity (89.43\%) and empirical \\
validity (84\%). The reliability calculation shows the high category (0.66). This study \\
concludes that the SPS questions developed are feasible to assess the process \\
skills of biology subjects at the junior high school level.
\end{tabular}

\section{INTRODUCTION}

To meet the challenges of the twenty first century in science and technology sectors, students must be equipped with the 21st century skills in order to compete in the globalization era. They are expected to master the 21st century skills in addition to excelling in their academic performance (Turiman et al., 2012). Basic and integrated science process skills are included in science process skills. This article only covers basic process skills. Basic science process skills are particularly relevant to foundational cognitive functioning in especially the elementary grades (Maison et al., 2019). Through hands-on activities like 
science experiments, students use totally different senses by touching, feeling, moving, observing, listening and smelling and generally dominant material to check. It helps students to progress from tier of concrete thinking to a lot of advanced level of thinking that promotes higher order thinking skills in twenty first century skills (Turiman et al., 2012). Biology is a science that cannot be separated from facts, concepts and principles related to living things and their interactions with the environment (Fadillah \& Angraini, 2018). Besides, biology functions also to discover a process through scientific procedures (Wahyuni et al., 2017).

Stated that science process skills are essential for students because they allow students to learn actively so that science will be useful in everyday life. Students' science process skills can be trained through media, approaches, methods and evaluation instruments (Yamtinah et al., 2017). Science process skills should be used by teachers in the effective delivery of science fact. This due to the fact that science is more than just a body of knowledge, it is also a method for systematically understanding the environment. Students must have science process skills in order to learn more about world of science and technology in depth. Students can learn science in a meaningful way by exploring science process skills based on the constructivist approach. Science process skills are not subject-specific, but they do push for subject spesific knowledge. There must be an assignment, some information to remember, or a problem to solve in order for the skills to be implemented (Yamtinah et al., 2017).

The development of tests to assess process skills is significant for secondary education students. There has been a lot of research done on the development of science process skills instruments. Among them is Rosana et al. (2017) created a non-test instrument in the form of performance to assess high school students science process skills. The performance appraisal instrument developed has an excellent category of usefulness response to measuring student SPS. Besides Lestari et al. (2016) developed an instrument in the form of description questions to measure SPS in high school chemistry subjects. The results showed that the instruments developed had a high value or were suitable for use. Science process skills are not hands-on skills using tools but thinking skills using science processes. This idea is in line with Ramadhani et al. (2015), assumption that written test questions are used to train students' abilities. In the context of SPS, it is expected that the ability of students to appear like scientists. This can be justified if the SPS questions used have good quality. Therefore, the SPS assessment can be done using a written test. Science process skills can be assessed through students' cognitive processes. This is in accordance with the opinion (Karamustafaoğlu, 2011) cognitive skills used to understand and develop information. This skill is applicable to all fields of science, and it reflect how scientists should behave when solving and planning experiment. Science process skills are fundamental skills that students must have in order to learn advanced skills in science subjects.

This purpose of this research is to create a written multiple-choice test instrument hat can be used to assess students' science process skills in junior high school in biology subjects. With the background of the importance of assessing science process skills and the limitation of SPS assessments in the form of written tests. Researches on SPS instrument making have been carried out in the form of non-test assessments, but the assessment in multiple choice questions form to measure SPS at the secondary school level is still limited. Akinbobola \& Afolabi (2010) and (Jalil et al., 2018) stated that the instrument for measuring SPS is not yet available in some schools. 


\section{RESEARCH METHODS}

This study is a type of development research $(R \& D)$ with a mode of procedural development. In general, the procedure for developing questions is shown in the following Figure 1.

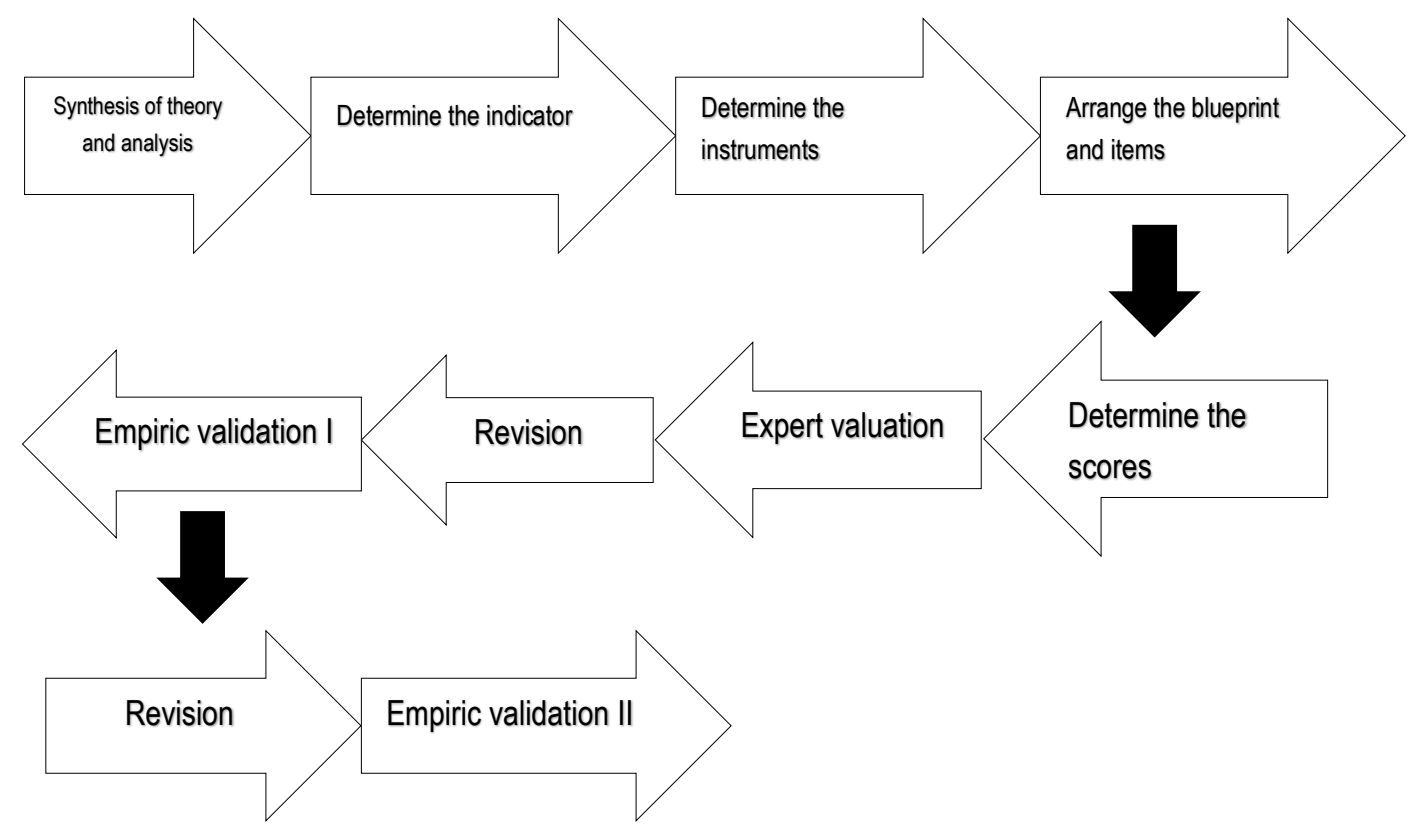

Figure 1. Procedural Development Model (Djaali \& Muljono, 2008)

The development research procedure consists of several stages, namely the theory synthesis stage and needs analysis, the design stage (synthesis of theory and analysis, determine the indicators, determine the instruments, arrange the blueprint and items) and the evaluation stage. The evaluation stage is divided into two parts, the validity test (both theoretical and empirical), the reliability test and the item analysis. The degree of difficulity, difference power, and distractor function are all examined during item analysis. Determining rational validity is done by searching in terms of content (content), form (construct), and language structure. Empirical validity stems from observations in the field. A revision and analysis of the items were carried out based on the validity results.

This theoretical validation was carried out by SPS questions design experts in terms of content, construct, and language structure. The results of theoretical validation were revisied, and the first stage of the empirical trial was carried out. Empiric validation of the trial's results was processed and revised, carried out by testing to 100 class VIII students at SMP 179 Jakarta. Sampling was done using cluster random sampling technique. Students are taken from the group randomly. This is considered a fair way of selecting a sample from a larger population because every member of the population has an equal chance of being selected.

The tests cover concept biology at junior high school levels of cognitive content and can be used to solve real-world problems. The research instrument is a test multiple choice given to the theoretical validator to get comments and assessments. A test was given to the practitioner. In this case, the junior high school science teacher get the responses to the questions developed. Instruments in empirical validation, namely multiple choice questions, are given to students to obtain the developed questions' quality and applicability. There are two kinds od data obtained: qualitative data and quantitative data. Qualitative data derived from the results of theoretical validation and practitioner responses are used to improve the product. 
In this study, data analysis used Microsoft Excel software to see the validity, reliability, and item analysis. Item analysis includes distinguishing power, difficulty level, and analysis of the distractor function. The validity of the items was determined using the proportional upper class and lower class which were determined first by calculating the upper 27 percent and the lower group. In searching for representatives of the upper or lower class, it is done by dividing the total number of students who responed correctly the question by the number of students in the class multiplied by $100 \%$. Then, after knowing the proportions, it can be seen the value in the table "proportion of correct responses at the lower 27 percent". If the rbis value of the upper group and the lower group is greater than 0.20 then it can be said that the question is valid and if it is less than 0.20 then it can be said that the question is invalid (Purwanto, 2013). Examination of the items validity is as follows in Table 1.

Table 1. The Criteria for The Validity of Items

\begin{tabular}{cc}
\hline Validity Coefficient & Criteria \\
\hline $0,00-0,19$ & Invalid \\
$\geq 0,20$ & Valid \\
\hline
\end{tabular}

The Spearman-Brown formula with the odd-even model was determine the test's dependability (Arikunto, 2013). A test can be said to be reliable if it meets the criteria listed in Table 2.

Table 2. The Criteria for The Reliability of Items

\begin{tabular}{cc}
\hline Reliability Coefficient & Criteria \\
\hline $0,00-0,20$ & Very poor \\
$0,20-0,40$ & Poor \\
$0,40-0,60$ & Quite \\
$0,60-0,80$ & Good \\
$0,80-1,00$ & Very Good \\
\hline
\end{tabular}

The difficulty index is calculated by adding up the correct answers from upper and lower class students and dividing the total number of students in the upper and lower groups by the total number of students in the upper and lower groups (Purwanto, 2013). The criteria for difficulty index criteria can be found in Table 3.

Table 3. Index Value Difficulty Problem

\begin{tabular}{cc}
\hline Index Value Difficulty Problem (P) & Criteria \\
\hline $0,00-0,24$ & Difficult \\
$0,25-0,76$ & Average \\
$0,77-1,00$ & Easy \\
\hline
\end{tabular}

The interpretation of the distinguishing power of the criteria proposed by (Purwanto, 2013) is presented in Table 4 as follows.

Table 4. Distinguishing Power Coefficients

\begin{tabular}{cc}
\hline Distinguishing Power Coefficients & Criteria \\
\hline $0,00-0,20$ & Poor \\
$0,21-0,40$ & Quite \\
$0,41-0,70$ & Good \\
$0,71-1,00$ & Very Good \\
\hline
\end{tabular}

Analysis of distractor is also needed in this case to find out whether the distractor is functioning or 
not. According to (Arikunto, 2013), a distractor can be said to be functioning if it is selected from at least $5 \%$ of the number of respondents.

\section{FINDINGS AND DISCUSSION}

Science Process Skills (SPS) questions are developed using a series of instrument development steps adapted from Djaali \& Muljono (2008) beginning the theoretical synthesis and analysis stage, progressing to the development stage, and concluding with the evaluation stage. At the theoretical synthesis and analysis stage, the researcher determines the research variables' constructs described in the variables' conceptual and operational definitions. In the first stage, the researcher also found that it is essential to develop appropriate SPS questions for junior high school students.

The design stage (synthesis of theory and analysis, determine the indicators, determine the instruments, arrange the blueprint and items) and the evaluation stage, which takes approximately two months. At this stage, determining the indicator to be measured, determining the type of instrument, arranging the instrument grid, writing instrument items, and scoring techniques. There are 9 indicators to be achieved in this study as according to Rustaman (2005) the indicators are: (a) observing; (b) classify; (c) communicate; (d) predict; (e) hypothesize; (f) interpretation; (g) designing experiments; (h) asking questions; and (i) apply the concept. This study's type of instrument was a multiple choice type with four answer choices $a, b, c$, and $d$. Then, the instrument blueprint arrangement is done by making a specification table containing indicators, item numbers, and items. Next, namely writing the instrument items and answer keys and scoring guidelines. The correct answers score is given a score of 1 , and incorrect answers are given a score of 0 .

The evaluation stage is divided into two, namely the validity test (theoretical/expert evaluation and empirical). At this stage, the researcher performs theoretical validation and empirical validation. Improvements from experts on theoretical validation are first, improvements from the material aspect, namely, there is a mismatch in determining indicators and a mismatch in determining the correct answer to several questions, furthermore, from the material aspect, namely the mismatch in determining answer choices and illogical answer choices. Third, an improvement from the constructed aspect, namely the unclear purpose of the questions (can be in the form of tables, pictures or graphics). Also, based on expert advice, there are improvements in sentence structure, punctuation, and capitalization. The following Table 5 explains the summary of the results of theoretical validation by experts.

Table 5. Summary of Theoretical Validation Results by Experts

\begin{tabular}{ccc}
\hline Indicators & Persentase & Criteria \\
\hline Materials & $90 \%$ & Very good \\
Construction & $86,7 \%$ & Good \\
Language & $91,7 \%$ & Very good \\
\hline
\end{tabular}

The indicator of competency achievement were determined based on the results of practitioners responeses to the question, $97.7 \%$ of the questions were according to the grade level, and $91,7 \%$ of the language used was correct. From a theoretical point of view, the answer choice has been followed by what was asked from the question. So, it can be seen that the three aspects assessed can be said to be good because the percentage of conformity is close to $90 \%$.

After doing theoretical validation by experts, empirical validity is carried out on junior high school students. Empirical validity is carried out to determine whether the developed problem measures what it is trying to measure. The empirical validity of 42 out of 60 questions was classified as valid and 18 
questions were invalid. The cause of invalid questions can be because students work together, the physical and psychological conditions of students are less favorable, besides the tendency of students to answer quickly but not correctly (Arifin, 2017). It can be seen that most of the questions are classified as valid, which means that the question can measure what it wants to measure. Table 6 displays the empirical validation results

Table 6. Results of Empirical Validity

\begin{tabular}{ccc}
\hline No & Characteristics & Results \\
\hline 1 & Empirical validity & 42 items were valid \\
& & 18 items were invalid \\
2 & Difficulty level & 31 items were easy \\
& & 28 items were moderate \\
3 & Differentiator potency & 1 item was hard \\
& & 25 items were poor \\
4 & & 17 items were fair \\
& Distractor function & 4 items were good \\
& & 4 items were bad \\
& & 87 distractor is functioning \\
\hline
\end{tabular}

Item analysis includes difficulty level, distinguishing power, and analysis of the distractor function. Based on the analysis results, it was obtained 31 easy questions, 28 moderate questions, and 1 hard question. There are more easy questions than the questions in the medium and difficult categories. The items in the easy category could be because the distractor did not function or most of the students answered correctly, which means that most students have understood the material asked by the (Yani et al., 2014). According to (Sudjana, 2009), a package of questions given to students should have a balance between difficult: medium: easy with a ratio of $3: 4: 3$ or $2: 5: 3$. Based on the data that has been obtained, it can be seen that the questions consist of easy questions, moderate and hard with a ratio of 31: 28: 1 . So it can be seen, from the developed problem has a level of difficulty with an unbalanced proportion.

Furthermore, the results of the disguishing power calculation obtained by the questions with poor distinguishing power: good: not good consecutively 25: 17: 4: 4. According to the findings of the analysis of the distinguishing power of empirical trials, questions classified as bad had a higher proportion than the others. According to (Natar, 2011) questions that have bad discriminating power are possible because, the answer key to the question items is not correct, the item has two or more correct answer keys, the measured competency is unclear, the distractor does not function, the material being asked is too hard, so that many students guess, most students who understand the material being asked think there is wrong information in the item in question. Arifin (2017) stated that the higher the coefficient of distinguishing power of an item, the more able it is to distinguish between students who master competence and students who lack competence. It can be generalized that the distinguishing power of the questions is mostly bad, so that it has not been said to be able to distinguish students in the upper and lower classes.

Reliability analysis is used to see how fixed or steady a test is in assessing the scores. It means that students' results will not differ when the same test is carried out on different occasions or different respondents simultaneously. Reliability test results show the number 0.66 (high). The calculated reliability value is 0.66 , which means that the SPS test questions developed have high test reliability (Purwanto, 2013). There are four factors that affect reliability: test length, score distribution, ideal difficulty level, and objectivity (Arifin, 2017). 


\section{CONCLUSION}

The instrument of science process skills skills is a measure of students' scientific abilities in conducting scientific investigations. The study's production instrument was a multiple choice test. The developed science process skills instrument developed is said to measure student science process skills because it meets the good question requirements, namely validity and reliability. It is evident from the empirical validity results. There are 42 items that are valid and have reliability with high reliability $(0.66)$. The results of validity by experts get good criteria. analysis of the level of difficulty there are 31 items were easy, 28 items were moderate , 1 item was hard. Analysis differentiator potency 25 items were poor, 17 items were fair, 4 items were good, 4 items were bad. Distractor function is 87 distractor is functioning and 73 distractor is not working. The results of the item analysis show that the instrument developed has various levels of difficulty, which are dominated by questions in the medium category and have various distinguishing powers which are dominated by low distinguishing power.

\section{ACKNOWLEDGMENT}

Thanks to all the respondents, grade VIII students of SMPN 103 and SMPN 179 Jakarta. An expression of gratitude also needs to be conveyed to the Board of Teachers and Principals of SMPN 103 and SMPN 179 Jakarta to allow research in the two schools. Gratitude countless for the VIII grade biology teacher at SMPN 103 and SMPN 179 Jakarta.

\section{REFERENCES}

Akinbobola, A. O., \& Afolabi, F. (2010). Analysis of science process skills in West African Senior Secondary School Certificate Physics Practical Examinations in Nigeria. American-Eurasian Journal of Scientific Research, 4(5), 234-240. Retrieved from https://www.researchgate.net/ publication/44279765

Arifin, Z. (2017). Kriteria instrumen dalam suatu penelitian. Jurnal Theorems (the Original Research of Mathematics), 2(1), 28-36. Retrieved from https://www.neliti.com/

Arikunto, S. (2013). Dasar-dasar evaluasi pendidikan (2nd ed.). Jakarta. Bumi Aksara.

Djaali, \& Muljono, P. (2008). Pengukuran dalam bidang pendidikan. Jakarta. Grasindo.

Fadillah, E. N., \& Angraini, E. (2018). Pengembangan modul praktikum genetika berbasis keterampilan proses sains untuk mahasiswa Program Studi Pendidikan Biologi. Edubiotik: Jurnal Pendidikan, Biologi Dan Terapan, 3(01), 34-42. https://doi.org/10.33503/ebio.v3i01.77

Jalil, S., Herman, Sidin Ali, M., \& Haris, A. (2018). Development and validation of science process skills instrument in physics. Journal of Physics: Conference Series, 1028(1). https://doi.org/10.1088/ 1742-6596/1028/1/012203

Karamustafaoğlu, S. (2011). Improving the Science Process Skills Ability of Science Student Teachers Using I Diagrams. Eurasian J. Phys. Chem. Educ, 3(1), 26-38. Retrieved from http://www.eurasian journals.com/index.php/ejpce

Lestari, S., Rosilawati, I., \& Kadaritna, N. (2016). Pengembangan Instrumen asesmen keterampilan proses sains pada materi garam hidrolisis. Jurnal Pendidikan dan Pembelajaran Kimia, V(3), 8798. http://jurnal.fkip.unila.ac.id/index.php/JPK/article/view/11962

Maison, Darmaji, Astalini, Kurniawan, D. A., \& Indrawati, P. S. (2019). Science process skills and motivation. Humanities and Social Sciences Reviews, 7(5), 48-56. https://doi.org/10.18510/ hssr.2019.756

Natar, K. (2011). Panduan analisis butir soal. Lampung. UNILA PRESS.

Purwanto, N. (2013). Prinsip-prinsip dan teknik evaluasi pengajaran. Bandung. PT Remaja Rosdakatya.

Ramadhani, D., Susanti, R., \& Zen, D. (2015). Pengembangan soal keterampilan proses sains pada pembelajaran biologi SMA. Jurnal Pembelajaran Biologi: Kajian Biologi Dan Pembelajarannya, 2(1), 96-108. https://doi.org/10.36706/fpbio.v2i1.4727 
Rosana, D., Ramadani, M., \& Dewi, K. (2017). The instrument for assessing the performance of science process skills based on nature of science (NOS). Cakrawala Pendidikan: Jurnal IImiah Pendidikan, 36(3), 435-445. https://doi.org/10.21831/cp.v36i3.14731

Rustaman, N. (2005). Stragtegi belajar mengajar biologi. Malang. Universitas Negeri Malang.

Sudjana, N. (2009). Penilaian Hasil Proses Belajar Mengajar (p. 168). Bandung: PT Remaja Rosdakatya.

Turiman, P., Omar, J., Daud, A. M., \& Osman, K. (2012). Fostering the 21st century skills through scientific literacy and science process skills. Procedia - Social and Behavioral Sciences, 59, 110-116. https://doi.org/10.1016/j.sbspro.2012.09.253

Wahyuni, S., Indrawati, I., Sudarti, S., \& Suana, W. (2017). Developing science process skills and problem-solving abilities based on outdoor learning in junior high school. Jurnal Pendidikan IPA Indonesia, 6(1), 165-169. https://doi.org/10.15294/jpii.v6i1.6849

Yamtinah, S., Masykuri, M., Ashadi, \& Shidiq, A. S. (2017). An analysis of students' science process skills in hydrolysis subject matter using testlet instrument. Advances in Social Science, Education and Humanities Research (ASSEHR)(, 158(December). https://doi.org/10.2991/ictte-17.2017.36

Yani, A., Asri, A. F., \& Burhan, A. (2014). Distraktor soal ujian semester ganjil mata pelajaran produktif di SMK Negeri 1 Indralaya Utara. Jurnal Pendidikan Teknik Mesin, 1(2), 98-115. Retrieved from https://ejournal.unsri.ac.id/index.php/ptm/article/view/7410 